This is an author produced version of a paper published in Journal of Molecular Histology. This paper has been peer-reviewed but does not include the final publisher proof-corrections or journal pagination.

Citation for the published paper:

Holmqvist B, Olsson CF, Svensson ML, Svanborg C, Forsell J, Alm P.

"Expression of nitric oxide synthase isoforms in the mouse kidney: cellular localization and influence by lipopolysaccharide and Toll-like receptor 4"

Journal of Molecular Histology, 2006, Vol: 36, Issue: 8-9, pp. 499-516. http://dx.doi.org/10.1007/s10735-006-9028-7

Access to the published version may require journal subscription. Published with permission from: Springer 


\section{Expression of nitric oxide synthase isoforms in the mouse kidney: Cellular localization and influence by lipopolysaccharide and Toll-like receptor 4}

Bo Holmqvist ${ }^{1}$, Christina Falk Olsson ${ }^{1}$, Maj-Lis Svensson ${ }^{2}$, Catharina Svanborg ${ }^{2}$, Johan Forsell ${ }^{1}$ and Per Alm ${ }^{1}$

${ }^{1}$ Department of Pathology, Inst. Clinical Sciences, Lund University, Sölvegatan 25, 22185 Lund, Sweden.

${ }^{2}$ Department of Microbiology, Immunology and Glycobiology, Inst. Medical Sciences, Lund University, Sölvegatan 23, 22185 Lund, Sweden.

Running head: Renal NOS expression and influence by LPS and TLR4

Corresponding author: Dr Bo Holmqvist, Inst. Clinical Sciences, Lund University, Sölvegatan 25, 22185 Lund, Sweden. Email: bo.holmqvist@med.lu.se, telephone: 46-(0)46173427

Submission: To Journal of Molecular Histology 


\begin{abstract}
We determined the cellular mRNA expression of all intrarenal nitric oxide (NO)-producing NO synthase (NOS) isoforms, endothelial NOS (eNOS) and neuronal NOS (nNOS) and inducible NOS (iNOS) in kidneys from wild type mice (WT) and immune deficient Toll-like receptor 4 (TLR4) mutant mice, during normal physiological conditions and during a shortterm (6-16 hours) endotoxic condition caused by systemically administered lipopolysaccaride (LPS). Investigations were performed by means of in situ hybridization and polymerase chain reaction amplification techniques. In WT, LPS altered the expression rate of all intrarenal NOS isoforms in a differentiated but NOS-isoform coupled expression pattern, with iNOS induction, and up- and down-regulation of the otherwise constitutively expressed NOS isoforms, e.g. eNOS and nNOS and an iNOS isotype. In TLR4 mutants, LPS caused none or a lowered iNOS induction, but altered the expression rate of the constitutive NOS isoforms. It is concluded that the intrarenal spatial relation of individual NOS-isoforms and their alteration in expression provide the basis for versatile NO-mediated renal actions that may include local interactions between NOS isoforms and their individual NO-target sites, and that the NOSisoform dependent events are regulated by TLR4 during endotoxic processes. These regulatory mechanisms are likely to participate in different pathophysiological conditions affecting NO-mediated renal functions.
\end{abstract}

Key words: immune response, inflammation, endotoxin, mouse mutants, kidney pathology, in situ hybridization 


\section{Introduction}

Nitric oxide (NO) is a free radical gas molecule that intervenes in a large number of fundamental cellular processes. The spatio-temporal regulation of the NO-producing enzyme nitric oxide synthase (NOS) is important for body organ physiology and pathophysiology (Kone et al. 2003; Mungrue et al. 2003; Valdivielso and Blantz 2002; Pallone and Mattson 2002). All major NO-producing NOS isoforms can be expressed in the kidneys, and they have been designated to exert specific individual functions under normal physiological conditions (see Wilcox 2000; Kone 1997, 1999, Mohaupt et al. 1994). However, in different toxic, and inflammatory conditions, the production of NO is affected that can be both beneficial and negative for the progress of the disease. In immune responses, NO may exert versatile actions in different defense mechanisms including protection against infectious organisms, recruitment of neutrophils, vascular function and platelet aggregation, and NO is also indicated to influence cellular proliferation, differentiation, and death (see Blantz and Munger 2002; Coleman 2001; Hickey et al. 2001). Three intrarenal NOS isoforms are considered to be the main producers of NO in the kidney, the inducible NOS isotype (iNOS) and the constitutively expressed endothelial NOS (eNOS) and neuronal NOS (nNOS). In the kidneys, NO has multiple functional roles concerning renal blood flow, tubular regulation and glomerular filtration, which in turn affect the general body homeostasis, and NO functions are therefore involved in cases of severe kidney dysfunctions and pathophysiology of different diseases affecting kidney functions (Shrier and Wang 2004; Heyman et al. 2000a; 2000b; Valdivielso and Blantz 2002). In systemic inflammatory processes such as during sepsis conditions, local endotoxin-influenced alterations in NO-production via immunological processes in the kidneys may be central for the severe symptoms of general hypotension and multiorgan failure (Schwartz and Blantz 1999. The cellular localization of the individual intrarenal NOS isoforms may therefore be important for NO-mediated kidney functions (Mungrue et al. 2003). Due to the diffusible properties NO can readily influence neighbouring cells, and the cellular localization for the individual NOS isoforms, and their regulation of expression and subsequent production of NO may therefore be crucial for local target actions by NO.

In the kidney, cell populations expressing the different NOS isoforms are spatially closely situated (see Wilcox 2000; Kone 1997, 1999, Mohaupt et al. 1994). In addition to NO autoregulation of iNOS expression itself, interactions between iNOS and other NOS isoforms have been indicated (Kone et al. 2003; Blantz and Munger 2002; Cattell 2002; Zhou et al. 2000; Schwartz and Blantz 1999; Schwartz et al. 1997). In pathophysiological events, the 
direct induction and further regulation of specific NOS isoform activity, and the subsequent actions by the specific NOS expressing cell types are indicated to be of central importance, and NO-actions during an immune response may possess different molecular targets and/or cell types (see Cohen et al. 2003, Hemish et al. 2003; Wang et al. 2003; Bogdan 2001; Liu et al. 1996; Traber 1996). Despite reports about the presence and spatial distribution of renal NOS isoforms based on detection of NOS proteins and quantitative gene expression studies (see Cattell 2002), there are few studies on spatial alterations in renal NOS mRNA expression in situ related to immunological response. Furthermore, experimental investigations describing influence by endotoxins (i.e. lipopolysaccaride, LPS) mainly concern iNOS expression limited to a few species (see Chou et al. 2002; Furusu et al. 1998; Bachmann et al. 1995; Ahn et al. 1994; Uije et al. 1994), and there is no conclusive data concerning the influence by endotoxins on the expression pattern of all intrarenal NOS isoforms or their relations. Therefore, we determined the detailed cellular expression of all individual NOS isoforms in the kidneys of mice during normal physiological and during an early phase of LPS-induced endotoxemia.

During inflammatory processes, the immune signaling pathways and the specific mediators causing changes in intrarenal NOS isoform expression, with subsequent alterations in NO-production and NO-actions, are poorly known. However, TLR4 is considered to be central in conveying LPS signaling (see Beutler 2003; Takeda and Kaisho 2003; Akira et al. 2001) which induces expression of iNOS and subsequent NO formation (Rao 2000; Stuehr and Marletta 1985). Importantly, tlr4 gene deficiencies in humans strengthen the central role for TLR4 in immunity and inflammation (see Takeda and Kaisho 2003; Bäckhed et al. 2001), and the putative influence by TLR4 on intrarenal NOS isoform expression and subsequent NO-activity may thus play an important role for kidney functions related to inflammatory conditions. The expression of TLR4 in the kidneys was recently reported in mice (Wolfs et al. 2002), however, nothing is known about renal TLR4 cellular relation to NOS isoforms or about its local regulatory properties. Furthermore, tlr4 gene mutant mice strains are important disease models for studies of TLR4 deficiencies (Poltorak et al. 1998; Qureshi et al. 1999a,b), whereas the NOS expression or alterations in response to endotoxins in these strains are unknown. In the present study we therefore determined the influence by TLR4 on the altered NOS-isoform expression during endotoximic conditions induced by LPS. The lack of iNOS induction in TLR4 immune deficient mutant strains enabled us to further characterize the differentiated expression pattern of constitutive NOS isoforms. The mRNA expression of the specific individual NOS-isoforms was investigated by means of in situ hybridization correlated with polymerase chain-reaction (PCR) techniques. 


\section{Materials and Methods}

\section{Animals}

Male mice of about 20-25 g body weight were used. The animals were kept under a normal day/night cycle with free access to food and water. The mice were bred at the Department of Pathology, University of Lund and at the Institute of Laboratory Medicine/Department of Microbiology, Immunology and Glycobiology, University of Lund. The animal experiments had been approved by the Malmö/Lund animal ethical committee.

The mRNA expression of renal NOS-isoforms (iNOS, eNOS and nNOS) was studied in wild-type (WT) and TLR4 deficient mice. The WT Balb/c strains studied comprised healthy and LPS-treated animals ( $n=6)$. For comparison of WT strains, one group of LPS-treated WT mice of an NMRI strain was tested for iNOS-expression $(n=3)$. The mRNA expression in TLR4 deficient mice was studied in LPS and non-treated tlr4 mutant strains (see Poltorak et al. 1998; Qureshi et al. 1999a,b). One strain lacks the whole TLR4 (tlr4 ${ }^{0 / 0}$; C57BL/10ScCr also named C57BL/10ScNCr, $n=9$ ), here referred to as TLR4-KO. The WT littermate C57BL/10ScSn (tlr4 ${ }^{+/+}$, a sub-line of C57BL/10, $\mathrm{n}=9$ ) was used as a control (here referred to as cWT-KO) to the TLR4-KO strain. The other TLR4 deficient mouse strain used possesses a point mutation of TLR4 (C3H/HeJ, here referred to as TLR4-pm, n=5) and its WT littermate $\mathrm{C} 3 \mathrm{H} / \mathrm{HeN}(\mathrm{n}=5$, here referred to as cWT-pm) was used as a control. The mutant control strains used (cWT for TLR4-KO and cWT for TLR4-pm) have an unaltered tlr4 gene. Mice of the $\mathrm{C} 57 \mathrm{BL} / 10 \mathrm{ScNCr}$ and $\mathrm{C} 57 \mathrm{BL} / 10 \mathrm{ScSn}$ strains were originally obtained from the Microbiology Tumor biology Centre at the Karolinska Institute, Stockholm, Sweden (kind gift from dr Robert Wallin). The NMRI mice were purchased from B\&K Universal, Stockholm, Sweden.

\section{Lipopolysaccharide treatment}

One injection of the endotoxin LPS (from Salmonella typhimurium, Sigma, St Louis, USA) was administered intraperitoneally (10 mg/kg). Animals were sacrificed between 2 hours (h) and $24 \mathrm{~h}$ after injection. In WT and cWT strains RT-PCR revealed a main peak of iNOS mRNA induction at $6 \mathrm{~h}$ after treatment (Figure 1). Obvious alterations in NOS mRNA expression were detected up to $16 \mathrm{~h}$ after LPS treatment. At $16 \mathrm{~h}$ there was no increased cell death (studied by TUNEL labeling) or nitrotyrosin immunoreactivity (not shown), thus showing no indication of long-term effects by NO at this time. Also, no obvious alterations were detected for the immunoreactive NOS isoform proteins. Therefore, analyses of the 
initial, short-term, effects by LPS were performed in animals from all experimental groups sacrified at $6 \mathrm{~h}$ and $16 \mathrm{~h}$ after LPS administration.

\section{PCR analyses and construction of RNA probes}

Polymerase chain reaction (PCR) amplifications were conducted for confirmation of NOSisoform mRNA identities and of TLR4 mRNA expression, and for isolation of the same NOS isoform specific fragments utilized for constructing RNA probes were applied for in situ hybridization. Semi-quantitative reverse transcriptase PCR (RT-PCR) was used for comparisons with in situ hybridization (ISH) concerning the relative differences in expression in treated and non-LPS treated WT, and for direct correlation to TLR4 expression. Individuals from the same experimental groups sampled at the same occasions were used for both PCR and in situ hybridization,

The same mouse NOS isoform mRNA fragments analyzed with PCR, for identification of double stranded cDNA and for semi-quantitative RT-PCR were targeted by the in situ hybridization probes: iNOS (pos. 1889-2443bp, acc. \# U43428), eNOS (pos. 1390-2513bp and 1390-3499bp, acc. \# U53142), nNOS (pos. 43-1443bp, acc. \# D14552), giving a fragment size for nNOS of 1400bp, iNOS of 561bp, and eNOS of 1123bp and 2109bp. For amplification and isolation of these NOS fragments the following primers were used (from 5’): iNOS sense; TAG AGA ACT CAA CCA CAC CT, iNOS antisense; GGT GTA GGACAA TCC ACA AC, eNOS sense; AGA GAT GGT CAA CTA TTT CCT GTC C, eNOS antisense (1,1 kb); GGC TGC CTT TCT CCA GTT GTT C, eNOS antisense (2.1 kb); GCG CAA TGT GAG TCC GAA AAT GCT. nNOS sense; TCA GGT TCC TGT GGG AGT CGT, nNOS antisense; GCG TAC TTG ACG TGG TTA CAG.

TLR4 expression was analyzed of “fragment D” (pos. 1541-1950bp), supposed not to be expressed in the presently used TLR4-KO strain (Quereshi et al. 1999b). The following primers were used (from 5’): TLR4 sense; TGA CAC CCT CCA TAG ACT TC and TLR4 antisense GGT ATA TCA GAA ATG CTA CA.

RT-PCR analyses were performed of total RNA isolated from WT (Balb/c), TLR4-KO and corresponding cWT kidneys. For isolation of total RNA, animals were sacrificed by decapitation, and one of the two kidneys was taken out. The same kidney area as used for in situ hybridization was microdissected out, and total RNA was extracted (RNAWIZTM, Ambion, USA).

Between 1-2 $\mu \mathrm{l}$ cDNA or 1-5 ng total RNA (the same concentration within the compared experimental groups) template was used, in a total volume of 50 or $100 \mu l$ reaction mixture containing AmpliTaq Gold ${ }^{\mathrm{TM}}$ (Perkin Elmer). PCR conditions used for amplification of iNOS 
was $94{ }^{\circ} \mathrm{C}$ 30s, $55^{\circ} \mathrm{C} \mathrm{30s,} 72{ }^{\circ} \mathrm{C}$ 60s, for eNOS $94{ }^{\circ} \mathrm{C} 30$ s, $60{ }^{\circ} \mathrm{C} 30$ s, $72{ }^{\circ} \mathrm{C}$ 60s, for nNOS 94 ${ }^{\circ} \mathrm{C} 30$ s, $58^{\circ} \mathrm{C} 30$ s, $72{ }^{\circ} \mathrm{C} \mathrm{60s,} \mathrm{and} \mathrm{for} \mathrm{TLR} 494^{\circ} \mathrm{C} \mathrm{30s,} 50^{\circ} \mathrm{C} 30$ s, $72{ }^{\circ} \mathrm{C}$ 60s. Positive controls included commercially available cDNA from mouse brain and heart (Clontech, USA). For the semi-quantitative RT-PCR analyses of relative differences in expression rates between experimental groups, samples were collected between 25 to 40 cycles every $5^{\text {th }}$ cycle. To determine the corresponding concentration of total RNA used for RT-PCR analyses, PCR amplification was performed of GADPH (G3PDH 0.45kb control amplimer set, Clontech, USA). The PCR products (10-15 ul) were separated by electrophoresis on a 1,0 or 1,2\% agarose gel. The relative differences in gel band intensities between experimental groups and in samples from different cycles (25-40) were analyzed under UV illumination, and were documented digitally. Only differences in band densities that were obvious with visual inspection were considered to represent actual relative differences in expression rate, which were further supported by analyzes with densitometry software (Quantity One, Macintosh version, BioRad, UK).

\section{In situ hybridization}

Digoxygenin conjugated RNA probes, anti-sense and sense, were constructed from plasmids containing the NOS isoform fragments isolated from mouse cDNA (see above), the same cDNA fragments were used as those analyzed with PCR and semi-quantitative PCR (see above). Gel bands of the predicted sizes for the individual isoforms were excised (30-50 $\mathrm{Ll}$ of the PCR products) and purified (Wizard PCR Preps DNA Purification System, Promega). The purified PCR products were ligated into pGEM-T Easy vector (Promega) and transformed into JM109 Competent cells (Promega). Bacterial colonies grown on agar plates were amplified in an overnight culture, and the plasmids were extracted (Midipreps,Wizard, Promega). The nucleotide sequence on both DNA strands was confirmed from three independent PCR amplifications (using ABI PRISM BigDye Terminator Cycle Sequencing kit (Perkin Elmer) and ABI Prism 3100 DNA sequencer).

For anti-sense probes plasmids were linearised with Aat II, and for sense probes plasmids were linearised with Sal I. In vitro transcription for DIG-labeling of probes was performed using SP6 and T7 RNA polymerase respectively (Boehringer Mannheim/Roche, Germany).

Animals were anaesthetized with intraperitoneal injections of ketamine $(100 \mathrm{mg} / \mathrm{kg}$ ip; Ketalar ${ }^{\circledR}$, Park Davis, Barcelona, Spain) and xylazin (15 mg/kg ip; Rompun ${ }^{\circledR}$, Bayer AG, Leverkusen, Germany), and were perfused through the left ventricle of the heart with $40 \mathrm{ml}$ of an ice-cold $4 \%$ paraformaldehyde (PFA) in phosphate buffered saline (PBS; pH 7.2). Kidneys were dissected out and immersed in the same fixative for $16 \mathrm{~h}$ at $8{ }^{\circ} \mathrm{C}$. Following 
immersion in cryoprotection, tissues were frozen in embedding medium (100\%), and cryosectioned $(10 \mu \mathrm{m})$. Sections were collected in parallel series on microscope slides (Super Frost, Merck, Germany).

Cryosections from all groups were processed simultaneously and under the same conditions, to allow comparisons between the experimental groups. Sections were heated to $50{ }^{\circ} \mathrm{C}$ and air-dried, and tissues were permeabilized with proteinase- $\mathrm{K}(2.5 \mu \mathrm{g} / \mathrm{ml})$ for $20 \mathrm{~min}$ at $37^{\circ} \mathrm{C}$. Following postfixation in PFA and treatment with acetic anhydride $(0.25 \%)$ for 10 min, sections were incubated (1-3 h at room temperature) in hybridization buffer (formamide $50 \%+5$ x saline sodium citrate (SSC) +5 x Denhardts solution (Sigma) $+250 \mu \mathrm{g} / \mathrm{ml}$ MRE600 tRNA (Roche) $+500 \mu \mathrm{g} / \mathrm{ml}$ denatured, sheared salmon testes DNA and 10\% dextran sulphate (Sigma)). Hybridization with 600-1000 ng/ml probe was performed in hybridization buffer for $16 \mathrm{~h}$ at $65^{\circ} \mathrm{C}$. Selected sections, adjacent to those incubated with the anti-sense probe, were hybridized with the sense probes, or with only hybridization buffer. Posthybridization rinses were performed in 5 x SSC for 30 min at room temperature, in 5 x SSC containing $30 \%$ formamide for $2 \times 15 \mathrm{~min}$ at $65^{\circ} \mathrm{C}$, in $0.2 \times S S C 2 \times 15 \mathrm{~min}$ at $65^{\circ} \mathrm{C}$, and in 0.2xSSC for $2 \times 15 \mathrm{~min}$ at room temperature. Selected sections, incubated with each probe, were post-treated with RNAse. Visualization of hybridized transcripts was performed by sequential incubation with a goat anti-DIG alkaline phosphatase-conjugated antibody for $16 \mathrm{~h}$ at $8^{\circ} \mathrm{C}$ (1:2000; Roche) and alkaline phosphatase reaction solution containing nitro-blue tetrazolium (NBT, 340 $\mu \mathrm{g} / \mathrm{ml}$, Roche), 5-Bromo-4-chloro-3-indolyl-phosphate (BCIP, $175 \mu \mathrm{g} / \mathrm{ml}$, Roche) and Levamisole (0.001 M, Sigma). The reaction was performed for 7-32 h. Sections were dehydrated in an alcohol serial, ended with xylol and were mounted in Histomount (Histolab, Gothenburg, Sweden).

Selected sections were processed for NOS immuno- and NADPHd histochemistry to evaluate the correspondence in localization of NOS proteins and NOS-activity in relation to NOS mRNA expression in situ. Cryosections, parallel to those used for in situ hybridization, were rinsed in PBS containing 0,3\% Triton X-100 (PBS-T) for 5 minutes, and were then incubated in $1 \% \mathrm{H}_{2} \mathrm{O}_{2}$ in PBS-T for 5 minutes, and rinsed in PBS-T ( $3 \times 5$ minutes). After incubation with normal serum for 45 minutes (sheep serum for eNOS and iNOS, and swine serum for nNOS), sections were incubated with primary antibodies for 16 h. The primary antibodies used have previously been shown to specifically detect their corresponding antigens: sheep anti-nNOS (diluted 1:16000, kind gift from professor P. Emson, Cambridge University, UK), rabbit anti-eNOS and anti iNOS (diluted 1: 1000, Affinity Bioreagents and Transduction Lab. USA). After incubation for 16h with primary antibodies, sections were incubated with a secondary biotinylated antibody (45 minutes for iNOS and nNOS, and $2 \mathrm{~h}$ for 
eNOS), at room temperature. NOS immunoreactive sites were visualized with 3'-diaminobenzidine tetrahydrochloride (DAB)-solution $(1 \mathrm{mg} / \mathrm{ml}, \mathrm{pH} \mathrm{7,6)}$ for iNOS and nNOS, and 0,5mg/ml for eNOS for 10 minutes) containing $0,03 \% \mathrm{H}_{2} \mathrm{O}_{2}$ (85 seconds for iNOS and nNOS, and 3 minutes for eNOS). Tissues were then dehydrated and mounted (as described above). Tamm Horsfall protein immunohistochemistry were tested on parallel sections to iNOS in situ hybridization labelled sections, that together with cellular morphology was used to define distal tubules, proximal epithelium, the loop of Henle and collecting ducts (c.f. Ahn et al 1994 and Wolfs et al 2002). For NADPHd histochemistry, cryosections were dried for 15 minutes at $37^{\circ} \mathrm{C}$ and thereupon rinsed in PBS $(\mathrm{pH} \mathrm{7,2)} \mathrm{for} 10$ minutes and then in 0,05 $\mathrm{M}$ Tris- $\mathrm{HCl}$ (pH 8,0) for 90 minutes. The sections were then incubated for 90 minutes at $37^{\circ} \mathrm{C}$ in a freshly prepared solution containing 1,5 mM of $\beta$-NADPH in reduced form (Sigma, USA), 1,1 mM NBT (Sigma, USA) and 0,2 \% Triton ${ }^{\circledR}$ X-100 (Merck, Germany) diluted in Tris-HCl. The sections were then rinsed in Tris $\mathrm{HCl}$ ( 3 minutes) and PBS ( 3 x 10 minutes), and were mounted and cover-slipped in Kaisers glycerol gelatine (Merck, Germany).

Microscopical analyses were performed in a transmission light microscope (Olympus AX60) using interpherence microscopy (Nomarski optics). The spatial labeling was compared between kidneys from the different experimental groups. Obvious differences in the relative number of cells and the labeling intensity of NOS mRNA-expressing cells were evaluated via an arbitrarily grading as high, moderate, low, or absent. Microscopical analyses were performed as blind-tests by two scientists (BH and PA).

\section{Results}

\section{LPS-treatment}

At 6 and 16 hours after LPS-treatment, all WT animals (WT, cWT-KO and cWT-pm) showed symptoms of endotoxinemia, such as drousiness and shiverings. Differently, the TLR4-mutant mice showed no (TLR4-KO) or minor (TLR4-pm) symptoms.

\section{NOS-isoform expression; specificity of detection and relation to TLR4 expression}

PCR analyses of total RNA by semi-quantitative RT-PCR (Figure 1) and of double stranded (ds) cDNA (not shown) possessed the same specific detection of the mRNA fragments for the individual NOS-isoforms as targeted by means of in situ hybridization. 
The probes and the protocol used for in situ hybridization produced a distinct labeling of specific NOS mRNA transcripts for all NOS-isoforms, with low or no backgrounds. High stringency conditions were used for the hybridization and post-hybridization procedures to ensure specific and high sensitivity for detection of specific transcripts, and to prevent possible cross-hybridization. The specificity of the method was further concluded by the lack of labeling when using the sense probes (Figures 2-4), or when incubating without probe, and from the lack of changes in labeling after RNAse treatment. In situ hybridization revealed that the spatial expression of the intrarenal NOS isoform mRNA expression, and the general distribution of immunocytochemical labeling and NADPHd activity were detected in the same renal cell types (Figures 2-4). The two different eNOS anti-sense probes labeled the same structures, although the larger $(2,1 \mathrm{~kb})$ provided a relatively stronger labeling intensity.

The distribution of mRNA labeling of all NOS-isoforms by in situ hybridization was consistent within the experimental groups, and displayed the same cellular labeling. The differences in labeling pattern between the experimental groups (LPS-treated WT and mutant mice) were consistent concerning spatial labeling, relative number of cells and labeling intensity (Figures 5-8). Since low amounts of mRNA transcripts may not be visualized if not highly concentrated in the individual cell(s), only obvious and consistent differences in labeling were used for statements regarding alterations in expression.

Immunocytochemistry of eNOS and iNOS proteins alone provided a relatively poor detection signal, with no detectable differences between the experimental groups. Furthermore, the eNOS antibodies produced unspecific cross-reaction with iNOS antigen. NADPHd histochemistry produced an unselective labeling of the NOS isoforms, which also could represent unspecific labeling of non-NOS NADPHd-depending enzymes. Therefore, although supporting the spatial expression of NOS mRNA detected by in situ hybridization, immunocytochemistry did not possess corresponding specificity for detection of all individual isoforms and was not used for further comparisons of expression changes.

\section{Spatio-temporal expression of NOS-isoforms}

The RT-PCR analyses demonstrated the differences in NOS expression in direct relation to the presence or lack of TLR4 expression (summarized in Figure 1).

WT and $c W T-K O$ : TLR4 was highly expressed in these strains. Compared to healthy animals, following LPS injection iNOS expression in WT had increased significantly after 6h, followed by a slight decline after 16h. nNOS expression possessed no detectable change after $6 \mathrm{~h}$, whereas a slight decrease was indicated after 16h. A slight decrease in TLR4 expression was indicated after the LPS injection (at 6h and 16h). In WT, eNOS expression showed no 
detectable change after 6 hours, but had decreased significantly at 16h. Differently in cWTKO (and compared to TLR4-KO), the eNOS expression had significantly decreased after 6h, but had almost recovered to the original expression level after $16 \mathrm{~h}$.

TLR4-KO: No TLR4 expression was detected in TLR4-KO animals. Compared to healthy animals, following LPS injection the expression of all NOS-isoforms had decreased after $6 \mathrm{~h}$, but had recovered to basal expression levels after 16h. The same temporal pattern was indicated for the constitutive iNOS isotype. The expression pattern for all NOS-isoforms, was significantly different to that for both WT and cWT-KO. In addition, in TLR4-KO the initial expression level of nNOS was indicated to be relatively high compared to the WT and cWT-KO.

In situ hybridization of labeled mRNA for all NOS isoforms are represented in figures 2 to 8, and the relative differences in number of labeled cells and labeling intensities are summarized in Table 1. The spatio-temporal labeling pattern corresponded well with the findings of relative changes in NOS isoform expression levels obtained with RT-PCR.

iNOS

\section{Non-treated and LPS-treated WT mice}

The same principal iNOS expression pattern was detected from LPS-treated WT and cWT-KO and cWT-pm mice at $6 \mathrm{~h}$ after LPS injections (Figures 2, 5, and 6). WT animals displayed a slightly higher expression concerning the number of cells and their labeling intensity compared to cWT's. No iNOS mRNA labeling was detected in untreated strains.

At 6 hours after LPS administration, high number of cells with strong iNOS mRNA labeling intensity was present in a large number of parietal epithelial cells of the Bowman's capsule (Figures 2 A and C). In cortical tubules, epithelial cells displayed high iNOS labeling intensity (Figures $2 \mathrm{M}-\mathrm{N}$ ). The cortical iNOS expressing tubules lacked Tamm Horsfall protein immunoreactivity, suggesting them to be proximal tubules of the nephron. Relatively high to low iNOS mRNA labeling intensities were present in cells within the papillae (Figures $2 \mathrm{H}$ and I) and on the papillary surface (Figures $2 \mathrm{E}$ ), and in a few putative mesangial cells of glomeruli.

In cWT's the labeling intensity was similarly high at $6 \mathrm{~h}$ after LPS administration (Figures 5 A, C-F, 6A, C-D), and was relatively more pronounced after 16 hours, and with the same distribution as in WT. In some cWT individuals, weak iNOS mRNA labeling was indicated in vascular endothelial cells in the medulla. 


\section{LPS-treated TLR4-KO mice}

Virtually no iNOS mRNA labeling was detected in TLR4-KO mice after LPS administration, neither at 6, nor at 16 hours (Figures 5 B and G, and 6 B, E and G). In some individuals $(\mathrm{n}=2)$, labeling was present in a few cells of the papillary surface after $6 \mathrm{~h}$, however not detected at 16h after LPS administration.

\section{LPS-treated TLR4-pm mice}

Relatively low iNOS mRNA labeling intensities were detected at $6 \mathrm{~h}$ after LPS administration in TLR4-pm compared to cWT-pm and WT mice, however in the same distribution. In TLR4-pm mice, iNOS labeling of low intensity was detected in relatively few parietal epithelial cells of the Bowman's capsule, and a few epithelial cells of tubules at all levels displayed iNOS labeling of moderate intensity (Figure $6 \mathrm{H}$ ). The papillae contained a high number of cells with moderate to low labeling intensities. The papillary surface possessed low numbers of iNOS expressing epithelial cells, with moderate to low labeling intensity (Figure 6 F).

\section{nNOS}

All strains displayed the same nNOS mRNA-expression exclusively in cells of the macula densa (MD), with differences in labeling intensities between the experimental groups (Figures 3 and 7 and Table 1).

\section{Untreated and LPS-treated WT and cWT strains}

In non-treated WT (Figure $3 \mathrm{~A}$ and B), cWT-KO and cWT-pm strains (Figure $7 \mathrm{~A}$ and B), a relatively weak to moderate nNOS mRNA expression was restricted to cells of MD.

At 6h after LPS treatment, nNOS mRNA expression was still restricted to MD cells in both WT and cWT, with an appreciable similar number of labeled cells and labeling intensity.

At 16 hours after LPS treatment, a significantly lower labeling intensity was indicated in the WT and cWT's (Figure 7 G-H) compared to healthy WT/cWT (Figure 3 A) and TLR4KO and TLR4-pm.

\section{LPS-treated TLR4-KO mice}

At $6 \mathrm{~h}$ after LPS injection, MD cells in TLR4-KO mice (Figure 7 D-F) displayed a relatively high nNOS mRNA labeling intensity compared to cWT and WT mice (Figure 7 A and B). This difference was even more pronounced at 16h after LPS injection (compare 7G 
with Figure $3 \mathrm{C}, \mathrm{E})$. Immunocytochemistry did not reveal any difference in nNOS protein content.

\section{LPS-treated TLR4-pm mice}

At $6 \mathrm{~h}$ after LPS treatment, nNOS mRNA labeling intensity in MD cells from TLR4-pm mice was a relatively high compared to cWT-pm and WT, with no apparent difference to that of TLR4-KO.

eNOS

The same spatial distribution of eNOS mRNA expression was detected in healthy and LPStreated individuals of all strains. In endothelial cells of larger blood vessels and arterioles, only the latter showed alterations in labeling intensity following LPS administration (Figures 4 and 8).

\section{Non-treated and LPS-treated WT strains}

eNOS mRNA expression in untreated WT, cWT-KO and cWT-pm, was represented by relatively low labeling intensities. The labeling was widespread, and detected in numerous endothelial cells in capillary loops of the glomeruli, and in endothelial cells of glomerular afferent and efferent arterioles, and arteries (Figures $4 \mathrm{~A}$ and B, 8 A-C, E-H). Endothelial cells of blood vessels with various sizes in the outer medulla displayed moderate labeling intensities.

At 6 hours after LPS administration the same distribution of eNOS mRNA-expressing cells was detected as in non-treated WT and cWT, however, with a relatively higher labeling intensity that was especially pronounced in endothelial cells of glomerular capillary loops (Figure $4 \mathrm{E}$ and F) and afferent and efferent arterioles Figure 4 A, E). In addition, a weak labeling was indicated in the inner medulla of LPS-treated WT animals, with no clear cellular association (Figure $8 \mathrm{I}$ ).

In cWT's (not shown), the eNOS expression was more pronounced at 16 hours after the LPS injection in cWT compared to both WT and TLR4-KO.

\section{LPS-treated TLR4-KO mice}

At $6 \mathrm{~h}$ after LPS administration the eNOS labeling in TLR4-KO showed the same distribution as in corresponding cWT's and WT (Figure $8 \mathrm{~J}-\mathrm{M}$ ), but the labeling intensity in capillary loops of the glomeruli was relatively low compared to cWT and WT. No labeling was detected in the inner medulla and papillae $(8 \mathrm{M})$. The low expression in LPS-treated 
TLR4-KO was even more pronounced at $16 \mathrm{~h}$ after LPS treatment (8 N, O). In larger vascular structures, TLR4-KO possessed a corresponding labeling intensity compared to cWT and the other strains (Figure 8).

\section{LPS-treated TLR4- pm mice}

Endothelial cells in capillary loops of glomeruli displayed a relatively low eNOS mRNA expression in LPS-treated (6 and 16h) TLR4-pm mice (not shown) compared to cWT-pm, although similar to that in TLR4-KO mice. Endothelial cells of larger vessels possessed a labeling intensity corresponding to cWT and WT. As in TLR4-KO, no or a very weak labeling was detected in the papillae.

\section{Discussion}

The present study demonstrates the distribution and cellular localization of expression for all individual intrarenal NOS isoforms in the mouse kidney, and their differentiated up- and down-regulated expression during LPS-induced endotoxemia, which is strongly influenced by TLR4. The alterations recorded during endotoxemia propose that all intrarenal NOS-isoforms may participate locally in different cellular processes with subsequent versatile effects on renal functions. The regulation of the differentiated expression of all renal NOS isoforms may be crucial to retain general body homeostasis during various states of disease.

Intrarenal nNOS mRNA and nNOS protein (nNOS immunoreactivity) is exclusively expressed by MD cells in normal healthy animals or following LPS-treatment of all strains studied, and there is no indication of nNOS mRNA expression outside MD in mice. Although nNOS protein has also been indicated in cells of the Bowman's capsule, in various epithelial and endothelial cells (Bachman et al. 1995, Wang et al. 1998, Roczniak et al. 1999, Wu et al. 1999, see also review by Ollerstam and Persson 2002), there is no evidence on its physiological significance at these locations.

To the best of our knowledge there are no previous reports on an altered nNOS-expression (mRNA or protein) in relation to an immunological response such as endotoxemia. The downregulation of nNOS mRNA expression together with the induction of iNOS and the relatively lowered eNOS expression in WT mice at $16 \mathrm{~h}$ after LPS treatment is in agreement with a disappearance of nNOS protein in human nephritic glomeruli accompanied by a high iNOS and a lowered eNOS protein content (Furusu et al. 1998). The participation of nNOS in endotoxemia is also supported by the different LPS-influenced expression patterns of both 
nNOS- and eNOS-expression in TLR4-KO, which lack inducible iNOS and TLR4 as mediators of this immunological response, which reasonably is mediated by other pathways. Alterations in nNOS by MD cells as part of compensatory interactions with eNOS expression have been indicated to participate in diseases such as diabetes mellitus (Welch and Wilcox 2002). In addition, NO production from induced iNOS expression in nearby located cells may influence nNOS expression in MD. Thus, altered nNOS expression during endotoxemia may have profound influence on coupled nNOS-eNOS functions, i.e. on the NO-mediated regulation of local renal circulation (Mungrue et al. 2003), renal hemodynamics and tubuloglomerular feed-back mechanisms (Mattson and Bellehumeur 1996, Kone 1997, Ollerstam and Persson 2002).

We detected a constitutive expression of an iNOS isotype in healthy mouse kidneys of all strains studied. A constitutively expressed iNOS may participate in the production of renal NO (see Ortiz and Gavin 2003, Chou et al. 2002, Kone 1999), and constitutively expressed iNOS is reported to be widespread and detectable by in situ hybridization in rat (Ahn et al. 1994, Mohaupt et al. 1994, Morrisay et al. 1994). The low amounts of such an isotype have raised doubts about its function (Cattell 2002). Still, in TLR4-KO, lacking the peak of iNOS induction, LPS caused changes in its expression indicating participation in the endotoxin response.

LPS-induced iNOS-expression in WT strains was visualized in situ in epithelial cells of cortical tubules, in parietal epithelial cells of Bowman's capsule, in cells of the papillary surface, in a few mesangial cells of some glomeruli, and in scattered macrophages in the interstitial space of the cortex. In rats, in situ iNOS mRNA-expression (Ahn et al. 1994) was induced in mesangial cells, medullar interstitial cells, and papillary surface epithelium but not in parietal epithelial cells of Bowmans capsule as in the mouse. The differences in iNOS mRNA expression in Bowmans capsule might reflect species differences, as previously suggested (Weinberg et al. 1995, Furusu et al. 1998). The physiological effect remains to be explored, however, there is a corresponding distribution of induced iNOS mRNA during endotoxemia in rodents and of iNOS protein in glomerulonephritis of humans (Furusu et al. 1998), in mesangial and parietal epithelial cells of glomeruli, and in interstitial cells. Moreover, in different pathophysiological NO-mediated events in renal diseases such as glomerulonephritis and tubular necrosis is iNOS considered as a major endotoxin-induced generator of NO (Traber 1996, Ochoa et al. 1991). In the present study of an early phase of endotoxemia we detected no increase in NOS immunoreactive proteins or cell death caused by LPS, thus indicating no severe NO mediated pathology at the initial stage (up to 16 hours) of the endotoxic processes. 
In WT mice following LPS administration, a steady decrease of eNOS and nNOS expression accompanied the increase of iNOS mRNA expression. It has previously been suggested that NO produced by iNOS possess an influence on eNOS and nNOS expression at a transcriptional regulation level, as shown for a great number of genes including those for iNOS itself (see Pfeilschifter et al. 2001). Furthermore, LPS- and cytokine-influenced variations in the regulation of eNOS mRNA expression have also been indicated (cf. Forstermann et al. 1998), and a LPS-evoked NO-inhibition of eNOS by NO produced from iNOS has previously been demonstrated in the kidney (Schwartz et al. 1997). The coupled changes in iNOS and eNOS expression are in correspondence with those found during endotoxemia and sepsis in different species including human (see Traber 1996), and are also in agreement with previous studies combining quantitative mRNA-expression and immunocytochemical localization of NOS-proteins, after LPS-treatment in rats and glomerulonephritis in humans (Liu et al. 1996, Schwartz and Blantz 1999, Bobadilla et al. 1998, Furusu et al. 1998, Cattell 2002). In general, induction of iNOS and NO produced as part of an immunological response may cause acute renal failure and dysfunction of different organs (see Schwartz and Blantz 1999, Heyman 2000a, 2000b, Shieh et al. 2000). In glomerular thrombotic microangiopathy in rats induced by endotoxin, histological and quantitative analyses of NOSproteins propose that eNOS-reduction is coupled with a significant increase in iNOS of different cell types (Zhou et al. 2002). In ischemia of the mouse kidney an increased synthesis of both eNOS- and iNOS-protein has been reported (Park et al. 2003). Thus, the severe consequences for renal and body physiology in endotoxemia and sepsis conditions may be due to the lowered nNOS and eNOS accompanied by the high increase in NO production of induced iNOS.

eNOS mRNA expression in kidneys from healthy mice of all strains was restricted to vascular endothelial cells of glomerular capillaries, and of small and larger arteries, which corresponds to findings in a previous in situ hybridization study performed in rats (Ujie et al. 1994) and an immunocytochemical study in human (Bachman et al.1995). In WT mice following LPSadministration, altered vascular eNOS expression was primarily noted in glomeruli and arterioles, but not in larger blood vessels. NO produced by eNOS in renal endothelial cells acts as a vasodilator, controlling the vascular tone in balance with different vasoconstrictors, and may thus be critical for renal hemodynamic functions (see review by Wilcox 2000). eNOS, in addition to iNOS, may possess a central role in human renal diseases affecting the glomeruli (Furusu et al. 1998). The complex regulation of eNOS expression in the kidney is influenced by a large number of compounds and physiological conditions (see review by Kleinert et al. 2003). An indirect influence on eNOS expression via altered iNOS expression has been indicated to affect glomerular function specifically (Cattell 2002, Zhou et al. 2000, Bobadilla et al. 1998). Thus, during 
endotoxemia the lowered eNOS expression in arterioles and glomeruli may be influenced by nearby produced NO, both from the iNOS cells in the Bowman's capsule and cortical tubules and from nNOS cells in MD. Consequently, the close spatial relation between the intrarenal eNOS-, nNOS- and iNOS-expressing cells and their specific target sites of the nephron further stresses high capacities for NO-mediated interactions at versatile functional divisions.

We noted that the relative expression of eNOS mRNA in cWT-KO was strongly diminished after $6 \mathrm{~h}$ but had returned to basal expression level after $16 \mathrm{~h}$. In the TLR4-KO strain, lacking induction of iNOS, the expression patterns of both eNOS and nNOS had significantly decreased after $6 \mathrm{~h}$ but had returned to basal expression levels after $16 \mathrm{~h}$. This is in contrast to the WT strain in which the eNOS mRNA level was significantly reduced after $16 \mathrm{~h}$. Hence, in addition to common and/or differential regulation of the isoform expression (see Cattell 2002, Liu et al. 1996), alterations in expression of NOS-isoforms may differ with respect to both inducing agent and TLR4 mediating capacities of the immune response.

We demonstrated that TLR4 deficiency altered the induction of iNOS and the regulatory expression of the constitutive NOS-isoforms. Subsequently, TLR4 can regulate total NOproduction and thereby influence the versatile NO-mediated actions during endotoxemia. This further supports the importance for TLR4 in the endotoxin-evoked inflammatory processes (Qureshi et al 1999a, b) and its central role in immune responses of human disease (see Bäckhed et al 2001, Svanborg et al. 2001a, b; Takeda and Kaisho 2003). The TLR4-dependent NOSexpression in the kidneys is indicated to be locally mediated in epithelial cells of cortical tubules and in glomeruli, due to the LPS-induction of iNOS expression in strains with intact TLR4. This is supported by recent studies showing a corresponding distribution of TLR4 expression in these structures (Tsuboi et al. 2002, Wolfs et al. 2002). In comparison, after renal inflammation caused by ischemia in a mouse model, the total TLR4 expression increased, preferentially in distal tubular epithelium, in the thin limb of Henle's loop and in collecting ducts (Wolfs et al. 2002), indicating that the local renal TLR4 expression may be differently regulated with respect to mode of inflammation.

The coupled role for TLR4 and induction of iNOS has been indicated in different organs, such as a TLR4-triggered iNOS expression and hyperpermeability in response to ozone exposure in the lungs (Jones et al. 2001, Kleeberger et al. 2001), and a correlated TLR4 expression with iNOS/NO actions in the myocardium during heart failure (Frantz et al. 1999). Furthermore, among macrophages the LPS-induced iNOS response is significantly higher in those that express high numbers of TLR4 (Dil and Qureshi 2002). In comparison, in kidneys it still needs to be concluded whether TLR4 regulation of constitutive NOS isoform expression occurs directly and/or indirect 
by TLR4 regulation of iNOS expression. In addition, over-expression of TLR4 causes a stronger response to LPS and promotes survival, suggesting a central role for TLR4 in long-term immunity (Bihl et al. 2003), which may include beneficiary alterations of NOS/NO actions.

Different cellular pathways and molecular factors, including NO it self, may be interacting with NOS in the activation and/or deactivation of NO production (Kone et al. 2003). In addition to the local renal LPS-TLR4-mediated effects, the intrarenal NOS expression can also be influenced by TLR4 of various extrarenal immune and inflammatory cell systems (i.e. macrophages and leucocytes) and thus mediated by various extrarenally produced cytokines, such as INF- $\gamma$, IL $-1 \beta$ and TNF- $\alpha$ (Beutler 2003). The present study also supports the occurrence of TLR4-iNOS independent pathways to LPS stimulation (see Haziot et al. 2001, Lorenz et al. 2001, Yang et al. 1998), as seen from the alterations in intrarenal constitutive NOS expression pattern in intrarenal constitutive NOS expression pattern following LPS treatment in TLR4 deficient strains with no or low iNOS induction. The relatively high expression of nNOS and eNOS in TLR4-KO mice may reflect compensatory mechanisms for the lack of iNOS expression, as indicated to occur in NOS transgenic mice (Park et al.2003). The spatial location and relation of the intrarenal NOS-isoform expressing cells, together with their capacities for differentiated expression during endotoxemia under the regulation of TLR4, may thus provide an important basis for the homeostasis of NOmediated renal functions of central importance in different renal pathophysiological conditions.

\section{Acknowledgement}

We thank Lillemor Thureson for excellent technical assistance concerning tissue handling and the immunocytochemical and histochemical investigations. This study was supported by VR (11205), the Royal Physiographic Society of Lund and local ALF-funds. 


\section{References}

Ahn KY, Mohaupt MG, Madsen KM, One BC (1994). In situ hybridization localization of mRNA encoding inducible nitric oxide synthase in rat kidney. Am J Physiol Renal Physiol 267:F748-F757.

Akira S (2001) Toll-like receptors and innate immunity. Adv Immunol. 78: 1-56.

Bachman S, Bosse HM, Mundel P (1995) Topography of nitric oxide synthesis by localizing constitutive NO synthases in mammalian kidney. Am J Physiol Renal Physiol 268: F885- F898.

Beutler B (2003) Science review: key inflammatory and stress pathways in critical illness the central role of the Toll-like receptors. Crit. Care 7: 39-46.

Blantz RC, Munger K (2002) Role of nitric oxide in inflammatory conditions. Nephron 90: 373-378.

Bobadilla NA, Gamba G, Tapia E, Garcia-Torres, Bolio A, Lopez-Zetina P, Herrera-Acosta J (1998) Role of NO in cyclosporine nephrotoxicity: effects of chronic NO inhibition and NO synthases gene expression. Am J Physiol 274: F791-F798.

Bogdan C (2001) Nitric oxide and the regulation of gene expression. Trends Cell Biol 11: 6675.

Bihl F, Salez L, Beaubier M, Torres D, Lariviere L, Laroche L, Benedetto A, Martel D, Lapointe JM, Ryffel B, Malo D (2003) Overexpression of Toll-like receptor 4 amplifies the host response to lipopolysaccharide and provides a survival advantage in transgenic mice. J Immunol 170: 6141-6150.

Bäckhed F, Söderhäll M, Ekman P, Normark S, Richter-Dahlfors A (2001) Induction of innate immune responses by escherichia coli and purified lipopolysaccharide correlate with organ- and cell-specific expression of toll-like receptors within the human urinary tract. Cell Microbiol 3: 153-158.

Cattell V (2002) Nitric oxide and glomerulonephritis. Kidney Int 61: 816-821.

Chou DE, Cai H, Jaydevappa, Porush JG (2002) Regional expression of inducible nitric oxide synthase in the kidney stimulated by lipopolysaccaride in the rat. Exp Physiol 87: 153162.

Cohen RI, Hassel AM, Ye X, Marzouk K, Liu SF (2003) Lipopolysaccharade down-regulates inducible nitric oxide synthase expression in swine heart in vivo. Biochem Biophys Res Comm 307: 451-458.

Coleman JW (2001) Nitric oxide in immunity and inflammation. Int Immunopharmacol 1: 1397-1406. 
Dil N, Quereshi MA (2002) Differential expression of inducible nitric oxide synthase is associated with differential Toll-like receptor-4 expression in chicken macrophages from different genetic backgrounds. Vet Immunol Immunopathol 84: 191-207.

Forstermann U, Boissel JP, Kleinert H (1998) Expressional control of the 'constitutive' isoforms of nitric oxide synthase (NOS I and NOS III). FASEB 12: 773-790.

Frantz S, Obzik L, Kim Y-D, Fukazawa R, Medzhitov R, Lee RT, Kelly RA (1999) Toll4 (TLR4) expression in cardiac myocytes in normal and failing myocardium. J Clin Invest 104: $271-280$.

Furusu A, Miyazaki M, Abe K, Tsukasaki S, Shioshita K, Sasaki O, Miyazaki K, Ozono Y, Oji T, Harada T, Sakai H, Ohno S (1998) Expression of endothelial and inducible nitric oxide synthase in human glomerulonephritis. Kidney Int. 53: 1760-1768.

Haziot A, Hijiya N, Gangloff SC, Silver J, Goyert SM (2001) Induction of a novel mechanism of accelerated bacterial clearance by lipopolysaccharide in CD14-deficient and Toll-like receptor 4-deficient mice. J Immunol 166: 1075-1078.

Hemish J, Nakaya N, Mittal V, EniOlopov G (2003) Nitric oxide activates diverse signaling pathways to regulate gene expression. J Biol Chem 278: 42321-42329.

Heyman SN, Darmon D, Goldfarb M, Bitz H, Shina A, Rosen S, Brezis M (2000a) Endotoxin-induced renal failure. I. A role for altered renal microcirculation. Exp Nephrol 8: 266-274.

Heyman SN, Rosen S, Darmon D, Goldfarb M, Bitz H, Shina A, Brezis M (2000b) Endotoxin-induced renal failure. II. A role for tubular hypoxic damage. Exp Nephrol. 8: 275-282.

Hickey MJ, Granger DN, Kubes P (2001) Inducible nitric oxide synthase (iNOS) and regulation of leucocyte/endothelial cell interactions: studies in iNOS-deficient mice. Acta Physiol Scand 173: 119-26.

Jones BW, Heldwein KA, Means TK, Saukonen JJ, Fenton MJ (2001) Differential roles of Toll-like receptors in the elicitation of proinflammatory responses in macrophages. Ann Rheum Dis 60: 6-12.

Kleeberger SR, Reddy SPM, Zhang L-Y, Cho H-Y, Jedlika AE (2001) Toll-like receptor 4 mediates ozone -induced murine lung hyperpermeability via inducible nitric oxide synthase. Am J Physiol Lung Cell Mol Physiol 280: L326-L33.

Kleinert H, Schwarz PM and Forstermann U (2003) Regulation of the expression of inducible nitric oxide synthase. Biol Chem. 384: 1343-1364.

Kone BC (1997) Nitric oxide in renal health and disease. Am J Kidney Dis 30: 311-333, 1997. 
Kone BC (1999) Localization and regulation of nitric oxide synthase isoforms in the kidney. Seminars in Nephrology 19:230-241.

Kone BC, Kuncewicz T, Zhang W, Yu ZY (2003) Protein interactions with nitric oxide synthases: controlling the right time, the right place, and the right amount of nitric oxide. Am J Physiol Renal Physiol 285:F178-F190.

Liu SF, Adcock IM, Old RW, Barnes PJ, Evans TW (1996) Differential regulation of the constitutive and inducible nitric oxide synthase mRNA by lipopolysaccharide treatment in vivo in the rat. Crit Care Med 24:1219-1225.

Lorenz E, Jones M, Wohlford-Lenane C, Meyer N, Frees KL, Arbour NC, Schwartz DA (2001) Genes other than TLR4 are involved in the response to inhaled LPS. Am $J$ Physiol Lung Cell Mol Physiol 281:L1106-L1114.

Mattson DL, Bellehumeur TG (1996) Neural nitric oxide synthase in the renal medulla and blood pressure regulation. Hypertension 28: 297-303.

Mattson DL, Higgins DJ (1996) Influence of dietary sodium intake on renal medullary nitric oxide synthase. Hypertension 27: 743-753.

Mohaupt M, Madsen KM, Wilcox CS, One BC (1994). Molecular characterization and localization of three nitric synthase isoforms in rat kidney. In: Moncada S, Feelisch M, Busse R, Higgs EA, eds. Biology of nitric oxide, New York: Portland Press, 4, 137-141.

Morrisay JJ, McCracken R, Kaneto H, Vehaskari, Montani D, Klahr S (1994) Location of an inducible nitric oxide synthase mRNA in the normal kidney. Kidney Int 45: 998-1005.

Mungrue IN, Bredt DS, Stewart DJ, Husain M (2003) From molecules to mammals: what's NOS got to do with it? Acta Physiol Scand 179: 123-35.

Ollerstam A, Persson AEG (2002) Macula densa neuronal nitric oxide synthase. Cardiovasc Res 56: 189-196.

Ochoa JB, Udekwu AO, Billiar TR, Curran RD, Cerra FB, Simmons RL, Peitzman AB (1991) Nitrogen oxide levels in patients after trauma and during sepsis. Ann Surg. 214: 621626.

Ortiz PA, Garvin JL (2003). Cardiovascular and renal control in NOS-deficient mouse models. Am J Physiol Regul Integr Comp Physiol. 284: R628-638.

Pallone TL, Mattson DL (2002) Role of nitric oxide in regulation of the renal medulla in normal and hypertensive kidneys. Curr Op in Nephrol and Hyperten 11: 93-98.

Park KM, Byun JY, Kramers C, Kim JI, Huang PL, Bonventre JV (2003). Inducible nitric oxide synthase is an important contributor to prolonged protective effects of ischemic preconditioning in the mouse kidney. J Biol Chem 278: 27256-27266. 
Pfeilschifter J, Eberhardt W, Beck KF (2001). Regulation of gene expression by nitric oxide. Pflugers Arch. 442: 479-86.

Poltorak A, He X, Smirnova I, Liu M-Y, van Huffel C, Du X, Birdwell D, al.ejos E, Silva M, Galanos C, Freudenberg M, Ricciardi-Castagnoli P, Layton B, Beutler B (1998) Defective LPS signaling in CEH/HeJ and C57BL/10ScCr mice: Mutations in TLR4 gene. Science 282: 2085-2088.

Qureshi ST, Larière L, Leveque G, Clermont S, Moore KJ, Gros P, Malo D (1999a) Endotoxin-tolerant mice have mutations in Toll-like receptor (tlr4). J Exp Med 189: 615-625.

Qureshi ST, Gros P, Malo D (1999b) The Lps locus: Genetic regulation of host responses to bacterial lipopolysaccharide. Inflamm res 48: 613-620.

Rao KMK (2000) Molecular mechanisms regulating iNOS expression in various cell types. $J$ Toxicol Environ Health 3: 27-58.

Roczniak A, Fryer JN, Levine DZ and Burns KD (1999) Downregulation of neuronal nitric oxide synthase in the rat remnant kidney. J Am Soc Nephrol 10: 704-713.

Schwartz D, Mendonca M, Schwartz I, Xia Y, Satriano J, Wilson CB, Blantz RC (1997) Inhibition of constitutive nitric oxide synthase (NOS) by nitric oxide generated by inducible NOS after lipopolysaccharide administration provokes renal dysfunction in rats. J Clin Invest 100: 439-448.

Schwartz D, Blantz RC (1999) Nitric oxide, sepsis, and the kidney. Seminars in Nephrology 19: $272-276$.

Shieh P, Zhou M, Ornan DA, Chaudry IH, Wang P (2000) Upregulation of inducible nitric oxide synthase and nitric oxide occurs later than the onset of the hyperdynamic response during sepsis. Shock 13: 325-329.

Shrier RW, Wang W (2004) Acute renal failure and sepsis. N. Eng. J. Med. 351: 159-169.

Stuehr DJ, Marletta MA (1985) Mammalian nitrate biosynthesis: mouse macrophages produce nitrite and nitrate in response to Escherichia coli lipopolysaccaride. Proc Natl Acad Sci USA 82: 7738-7742.

Svanborg C, Bergsten G, Fischer H, Frendéus B, Godaly G, Gustafsson E, Hang L, Hedlund M, Karpman D, Lundstedt AC, Samuelsson M, Samuelsson P, Svensson M, Wullt B (2001a) The innate host response protects and damages the infected urinary tract. Ann Med 33: 563-570.

Svanborg C, Frendéus B, Godaly G, Hang L, Hedlund M, Wachtler C (2001b) Toll-like receptor signaling and chemokine receptor expression influence the severity of urinary tract infection. J Inf Dis 183: S61-S65. 
Takeda K, Kaisho T (2003) Akira S. Toll-like receptors. Annu Rev Immunol 21: 335-376.

Traber DL (1996) Presence and absence of nitric oxide synthase. Crit Care Med 24: 11021103.

Tsuboi N, Yoshikai Y, Matsuo S, Kikuchi T, Iwami KI, Nagai Y, Takeuchi O, Akira S, Matsuguchi T (2002) Roles of toll-like receptors in C-C chemokine production by renal tubular epithelial cells. J Immunol 169: 2026-2033.

Ujie K, Yuen J, Hogarth L, Danziger R, Star RA (1994) Localization and regulation of endothelial NO synthase mRNA expression in rat kidney. Am J Physiol 267: F296-302.

Valdivielso JM, Blantz RC (2002) Acute renal failure: is nitric oxide the bad guy? Antioxid Redox Signal. 4: 925-934.

Wang X, Lu M, Gao Y, Papapetropoulos A, Sessa WC, Wang W (1998) Neuronal nitric oxide synthase in expressed in principal cell of collecting duct. Am J Physiol Renal Physiol 275: F395-F399.

Wang W, Jittikanont S, Falk SA, Li P, Feng L, Gengaro PE, Poole BD, Bowler RP, Day BJ, Crapo JD, Schrier RW (2003) Interaction among nitric oxide, reactive oxygen species, and antioxidants during endotoxemia-related acute renal failure. Am J Physiol Renal Physiol 284: F532-F537.

Welch WJ, Wilcox CS (2002) What is brain nitric oxide synthase doing in the kidney? Curr Opin Nephrol Hypertens. 11: 109-115.

Weinberg JB, Misukonis MA, Shami PJ, Mason SN, Sauls DL, Dttman WA, Wood ER, Smith GK, McDonald B, Bachus KE (1995) Human mononuclear phagocyte inducible nitric oxidase synthase (iNOS): Analysis of iNOS mRNA, iNOS protein, biopterin, and nitric oxide production by blood monocytes and peritoneal macrophages. Blood 86: 1184-1195.

Wilcox CS (2000) L-arginine-nitric oxide pathway. In: Seldin GW, Giebisch G (eds). The kidney, physiology and pathophysiology, New York: Raven Press, p. 849-871.

Wolfs TGAM, Buurman WA, van Schadewijk A, de Vries D, Daemen MARC, Hiemstra PS, van't Veer C (2002) In vivo expression of Toll-like receptor 2 and 4 by renal epithelial cells: IFN- $\beta$ and TNF- $\alpha$ mediated up-regulation during inflammation. J Immunol 168: 1286-1293.

Wu F, Park F, Cowley jr AW, Mattson DL (1999) Quantification of nitric oxide synthase activity in microdissected segments of the rat kidney. Am J Physiol Renal Physiol 276: F874-F881.

Xue C, Johns RA. Upregulation of nitric oxide synthase correlates temporally with onset of pulmonary vascular remodeling in the hypoxic rat. Hypertension 28: 743-753. 
Yang RB, Mark MR, Gray A, Huang A, Xie MH, Zhang M, Goddard A, Wood WI, Gurney AL, Godowski PJ (1998) Toll-like receptor-2 mediates lipopolysaccharide-induced cellular signalling. Nature 395: 284-288.

Zhou XJ, Laszik Z, Ni Z, Wang XQ, Brackett DJ, Lerner MR, Silva FG, Vaziri NT (2000) Down-regulation of renal endothelial nitric oxide synthase expression in experimental glomerular thromotic microangiopathy. Lab Invest. 80: 1079-1087. 


\section{FIGURE LEGENDS}

\section{Figure 1.}

RT-PCR determinations of mRNA expression pattern of intrarenal NOS isoforms (iNOS, nNOS, eNOS) and TLR4 in kidneys from healthy (0h) and LPS treated (6h and 16 hours after injection) mouse strains, wild type Balb/c (WT, n=3), tlr4 gene mutant (TLR4-KO, n=3), and the TLR4-KO wild type control (cWT, n=3). Note in TLR4-KO the lack of iNOS induction, and the presence of non-LPS-inducible, constitutively expressed, iNOS transcripts. Expression of GADPH depicts the relative amount of RNA used for the experimental groups.

\section{Figure 2.}

iNOS mRNA expression in kidneys from WT mice 6h after LPS treatment (blueish precipitates in A, C, E, H, I, M and N) visualized by in situ hybridization. Induced iNOS mRNA expression in Bowmans capsule (A, C and N), in scattered tubular cells within and at the surface of papillae (E), in epithelial cells of cortical tubuli (A and M) and in tubuli of the medulla (H and I). No labeling by iNOS RNA sense probes (B, D, F and J). Labeled mRNA transcripts are restricted to the cytoplasm around the nuclear membrane ( $\mathrm{M}$ and $\mathrm{N}$ ).

iNOS immunoreactivity (brownish) in the papillae (G) and medulla (K) at 16h after LPS injection of WT. NADPHd positive staining (blue-blackish in L and $\mathrm{O}$ ) in corresponding iNOSmRNA expressing structures (adjacent sections in A and $\mathrm{M}$ ).

Scale bars in A represents $100 \mu \mathrm{m}$ in $\mathrm{A}$ and $\mathrm{B}$, in $\mathrm{C}$ represents $40 \mu \mathrm{m}$ in $\mathrm{C}$ and $\mathrm{D}$, in $\mathrm{E}$ represents $50 \mu \mathrm{m}$ in $\mathrm{E}, \mathrm{F}$ and $\mathrm{G}$, in $\mathrm{H}$ represents $50 \mu \mathrm{m}$ in $\mathrm{H}, \mathrm{J}, \mathrm{K}$ and L. Scale bar in I represents $10 \mu \mathrm{m}$, scale bar in $\mathrm{M}$ represents $20 \mu \mathrm{m}$ in $\mathrm{M}$ and $5 \mu \mathrm{m}$ in $\mathrm{N}$, and in $\mathrm{O}$ represents $40 \mu \mathrm{m}$.

\section{Figure 3.}

nNOS mRNA expression in MD of WT visualized by in situ hybridization (blueish precipitates in A, C, E), nNOS immunoreactivity (brownish in B, D and F) and NADPHd positive staining (blue-blackish in G). In G, note NADPHd positive staining in endothelial cells of glomeruli, corresponding to eNOS mRNA expression (below).

Scale bar in A represents $25 \mu \mathrm{m}$ in $\mathrm{A}-\mathrm{G}$.

\section{Figure 4.}

In situ hybridization of eNOS mRNA expression by different vascular kidney structures (blueish precipitates in A, B, E and F), in different blood vessels in the outer medulla 
(scattered in A) including larger vessels (asterisks in A, B and E), and in afferent and efferent glomerular arterioles in the cortex (arrows in E). No labeling occur when using the eNOS sense probes ( $C$ and D). For comparison, both NADPHd positive staining (G, blueish-black) and eNOS immunolabeling (H, brownish) occur in correspondingly labeled blood vessels and glomerular arterioles. All images are from LPS-treated WT mice.

Scale bars: in A represents $50 \mu \mathrm{m}$ in A and C, in B represents $5 \mu \mathrm{m}$ in B and D, in E

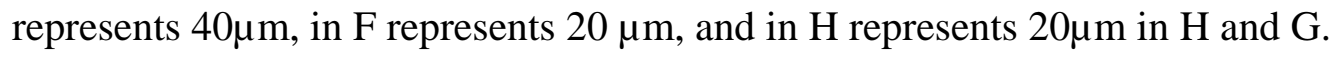

\section{Figure 5.}

In situ hybridization of iNOS mRNA expression at 6h after LPS injection in cWT mice (blueish labeling in A, C, D, E and F), in epithelial cells of the Bowmans capsule (A and E) and in cortical tubuli in both the upper and lower medulla (C, D and F). No LPS-induced iNOS mRNA expession in TLR4-KO mice (B and G). Note the corresponding distribution of induced iNOS mRNA expression in WT Balb/c (Figure 2).

Scale bars: in A represents $50 \mu \mathrm{m}$ in A, B, C and D, and in E represents $40 \mu \mathrm{m}$ in E, F and G.

\section{Figure 6.}

In situ hybridization of iNOS mRNA expression in medullary structures of cWT $6 \mathrm{~h}$ after LPS injection. Expression occurs by cells located within and on the surface of the papillae (A and C) and in endothelial cells of blood vessels (D). No iNOS mRNA expression was detected in TLR4-KO mice (B and G), whereas a weak widespread expression was present at the level of the inner medulla in TLR4-pm (H). In some TLR4 (E) and TLR4-pm mice (F) a few of iNOS mRNA expressing cell were located in the papillary surface.

Scale bars: in A represents $50 \mu \mathrm{m}$ in A, B, G and H, in C represents $5 \mu \mathrm{m}$ in C and D, and in $\mathrm{E}$ represents $40 \mu \mathrm{m}$ in $\mathrm{E}$ and $\mathrm{F}$.

\section{Figure 7.}

In situ hybridization nNOS mRNA in MD at $6 \mathrm{~h}$ after LPS-injection. Note the relatively lower nNOSmRNA expression in WT (A and B) compared to TLR4-KO mice (D-F) and barely detectable nNOSmRNA expression in WT mice at 16h after LPS-injection (G). The levels of immunoreativity of nNOS protein in WT after LPS-injection (6h (C) or 16h (H)) was restricted to $\mathrm{MD}$.

Scale bar in A represents $30 \mu \mathrm{m}$ in A, D, G and H). Scale bar in B represents $25 \mu \mathrm{m}$ in B, $\mathrm{C}$ E, and F. 


\section{Figure 8.}

In situ hybridization of eNOS mRNA in normal healthy WT mice (A-D), LPS-treated WT (E-I) and TLR4-KO (J-O) mice. A relatively high expression in glomeruli and arterioles (arrows) of healthy animals (A-C) $6 \mathrm{~h}$ after LPS-injection (E-I), whereas unchanged expression was noted in larger blood vessels (asterisks in $8 \mathrm{~B}$ and $8 \mathrm{H}$ ). eNOSmRNA expression was detected in the medulla of healthy WT (8D). Expression in tubular epithelial cells at $6 \mathrm{~h}$ after LPS-injection (8 I). Low eNOS expression in glomeruli and arterioles of TLR4-KO is low at $6 \mathrm{~h}(8 \mathrm{~J}-\mathrm{M})$ and almost absent at 16h (N and O) after LPS treatment, whereas unchanged in larger blood vessels (asterisk in $\mathrm{O}$ ).

Scale bars: in A represents $150 \mu \mathrm{m}$ in A, D, I, F and M, represents $300 \mu \mathrm{m}$ in E, K and N, represents $30 \mu \mathrm{m}$ in $\mathrm{C}$, and represents $50 \mu \mathrm{m}$ in $\mathrm{B}, \mathrm{G}, \mathrm{H}, \mathrm{J}, \mathrm{M}$, and $\mathrm{O}$. 


\begin{tabular}{|l|l|l|l|l|l|l|}
\hline & iNOS & & & nNOS & eNOS & \\
\hline Renal structure & $\begin{array}{l}\text { Cortex } \\
\text { (tubular } \\
\text { epithelial } \\
\text { cells) }\end{array}$ & $\begin{array}{l}\text { Medulla } \\
\text { (tubular } \\
\text { epithelial } \\
\text { treatls) }\end{array}$ & $\begin{array}{l}\text { Papillae } \\
\text { (center } \\
\text { and } \\
\text { surface) }\end{array}$ & $\begin{array}{l}\text { Macula } \\
\text { densa }\end{array}$ & $\begin{array}{l}\text { Vascular } \\
\text { endothelium } \\
\text {-arterioles }\end{array}$ & $\begin{array}{l}\text { Vascular } \\
\text { endothelium } \\
\text {-large blood } \\
\text { vessels }\end{array}$ \\
\hline $\begin{array}{l}\text { WT } \\
\text { Healthy }\end{array}$ & - & - & - & + & + & ++ \\
\hline $\begin{array}{l}\text { WT } \\
\text { 6h LPS }\end{array}$ & +++ & +++ & +++ & + & +++ & ++ \\
\hline $\begin{array}{l}\text { cWT TLR4-KO } \\
\text { 6h LPS }\end{array}$ & +++ & +++ & +++ & + & +++ & + \\
\hline $\begin{array}{l}\text { TLR4-KO } \\
\text { 6h LPS }\end{array}$ & - & - & $-(+)$ & +++ & + & ++ \\
\hline $\begin{array}{l}\text { cWT TLR4-pm } \\
\text { 6h LPS }\end{array}$ & +++ & ++ & ++ & + & ++ & ++ \\
\hline $\begin{array}{l}\text { TLR4-pm } \\
\text { 6h LPS }\end{array}$ & + & + & + & ++ & + & ++ \\
\hline
\end{tabular}

Table 1. Distribution of intrarenal NOS-isoform expression detected with in situ hybridization in healthy WT, and in LPS WT treated strains (i.e. WT (Balb/c and NMRI strains), TLR4-KO and TLR4pm mutant strains and the respective mutant control strains (cWT TLR4-KO and cWT TLR4-pm). WT healthy animals are compared with animals at 6 hours after LPS injection. The estimated labeling intensity is indicated as high $(+++)$, moderate $(++)$ or low $(+)$. In TLR4-KO denotes the scarce iNOS expressing cells in the papillar surface epithelium of some individuals $(-(+))$.

A minimum of five individuals from each strain and treatment were analyzed, of which at least three individuals were processed simultaneously for each NOS isoform labeling, at a minimum of three different occasions. See also representative images in Figures 2-8

Holmqvist et al 2005: Renal NOS expression and influence by LPS and TLR4. 


\section{Figure 1}

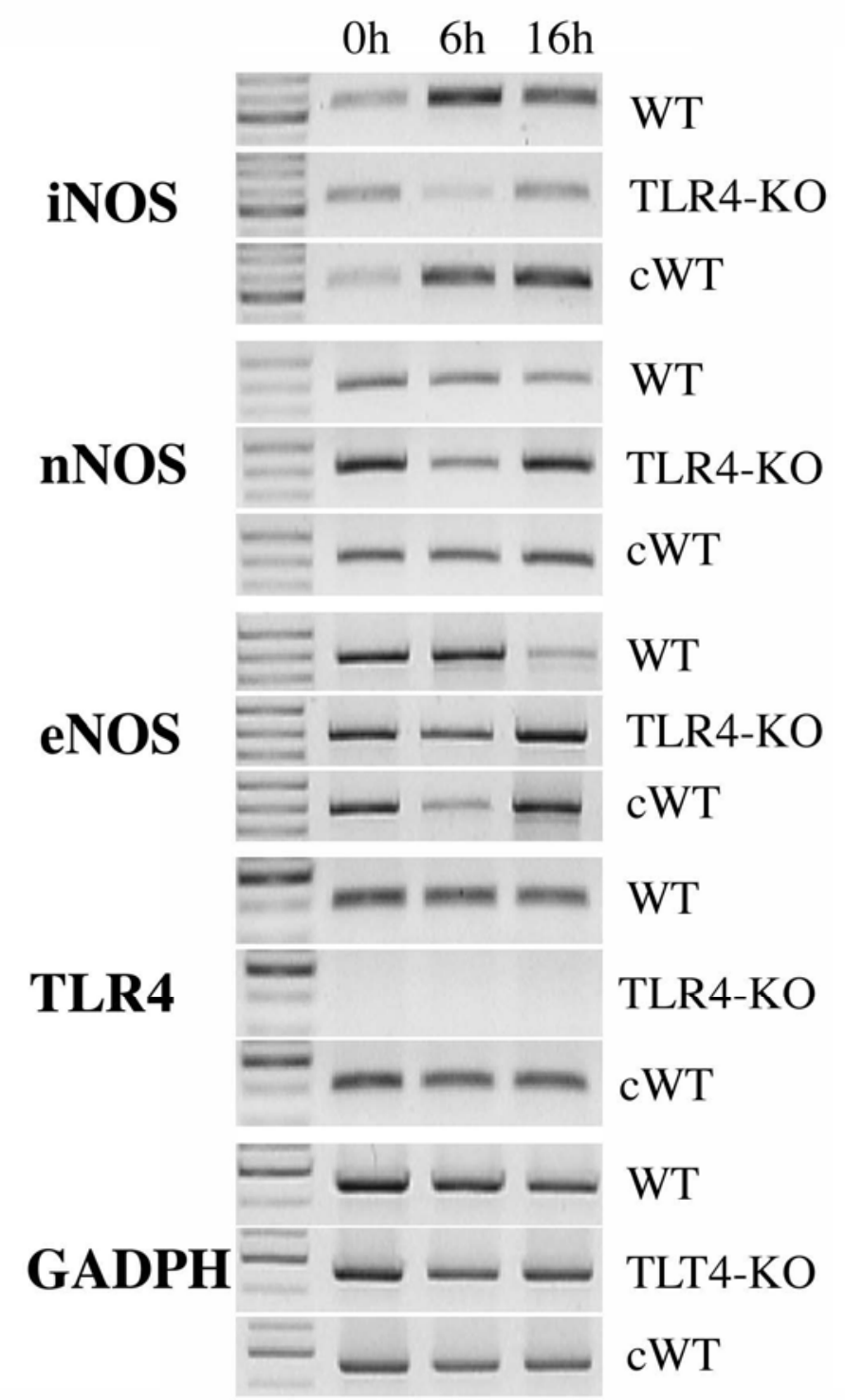

Holmqvist et al 2006 


\section{Figure 2}

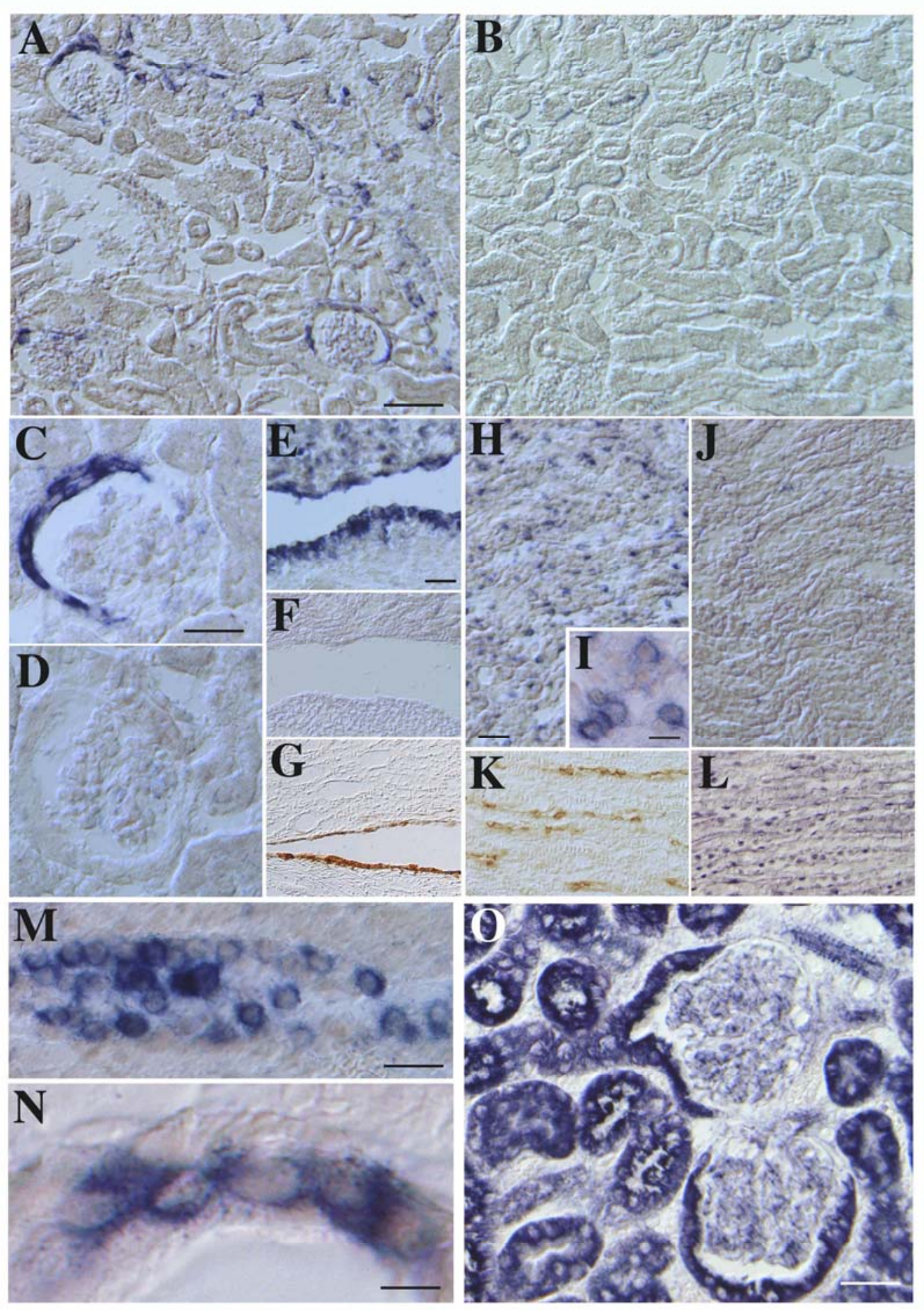


Figure 3

Holmqvist et al 2006
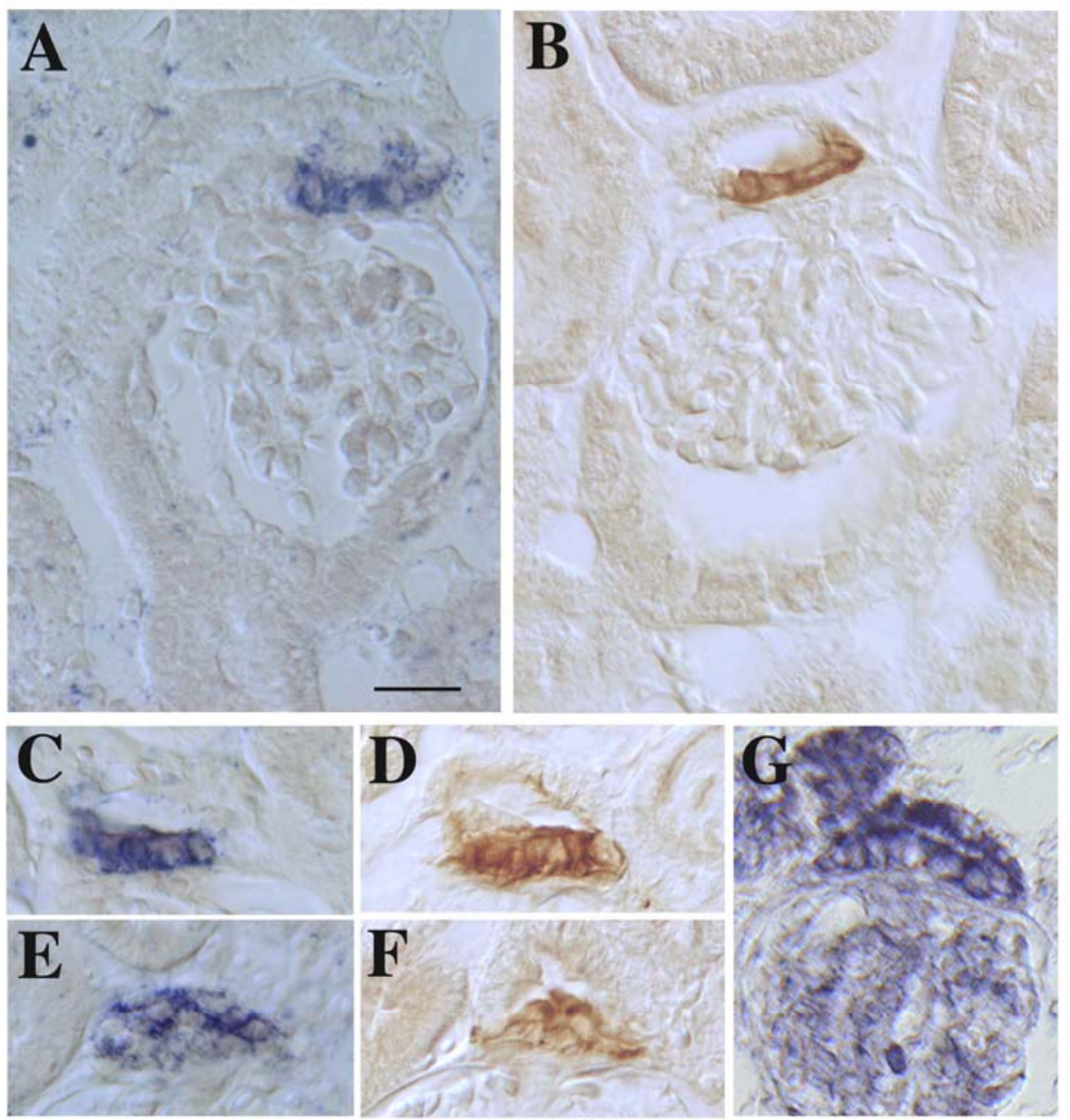
Holmqvist et al 2006

Figure. 4

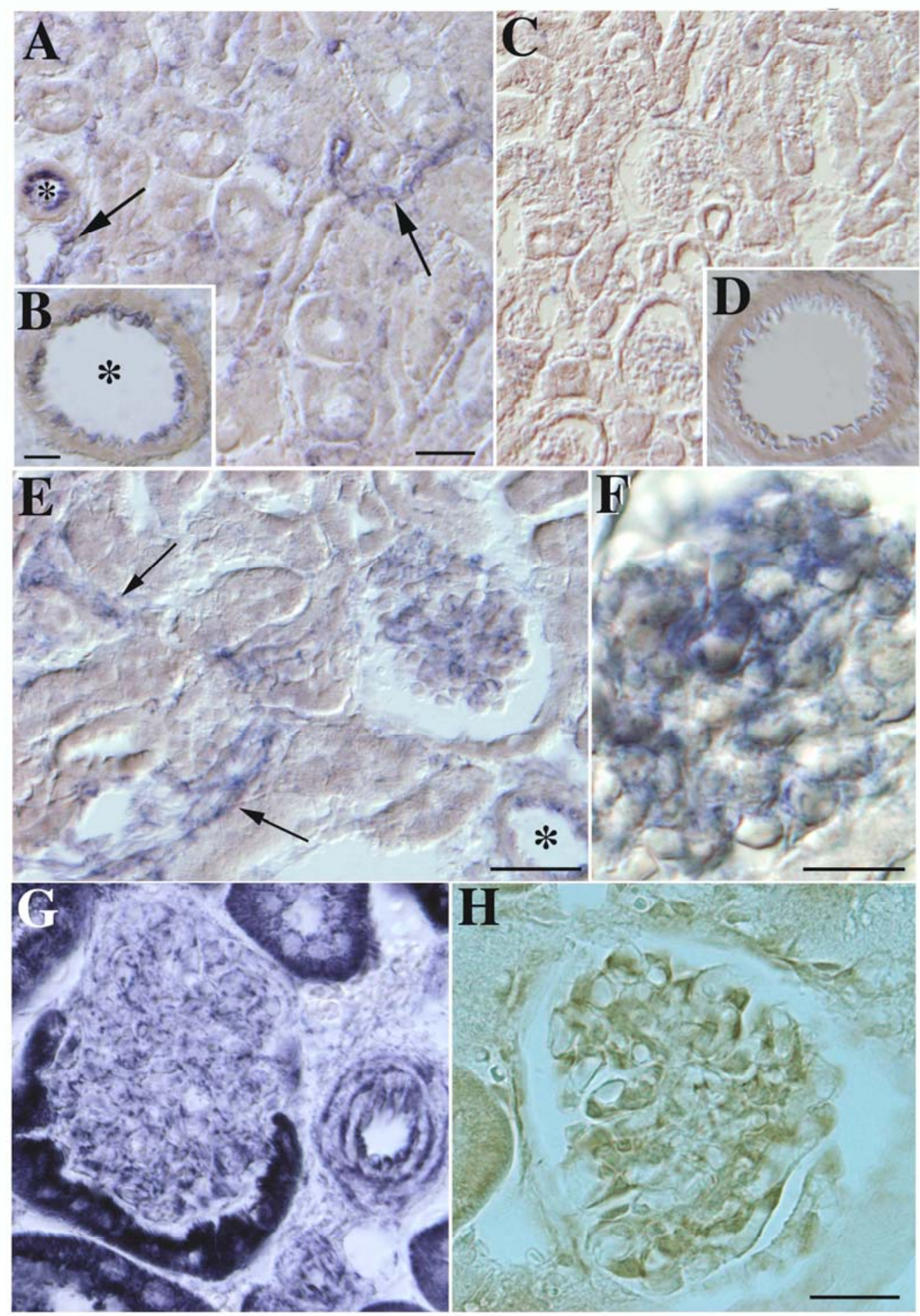


Figure 5

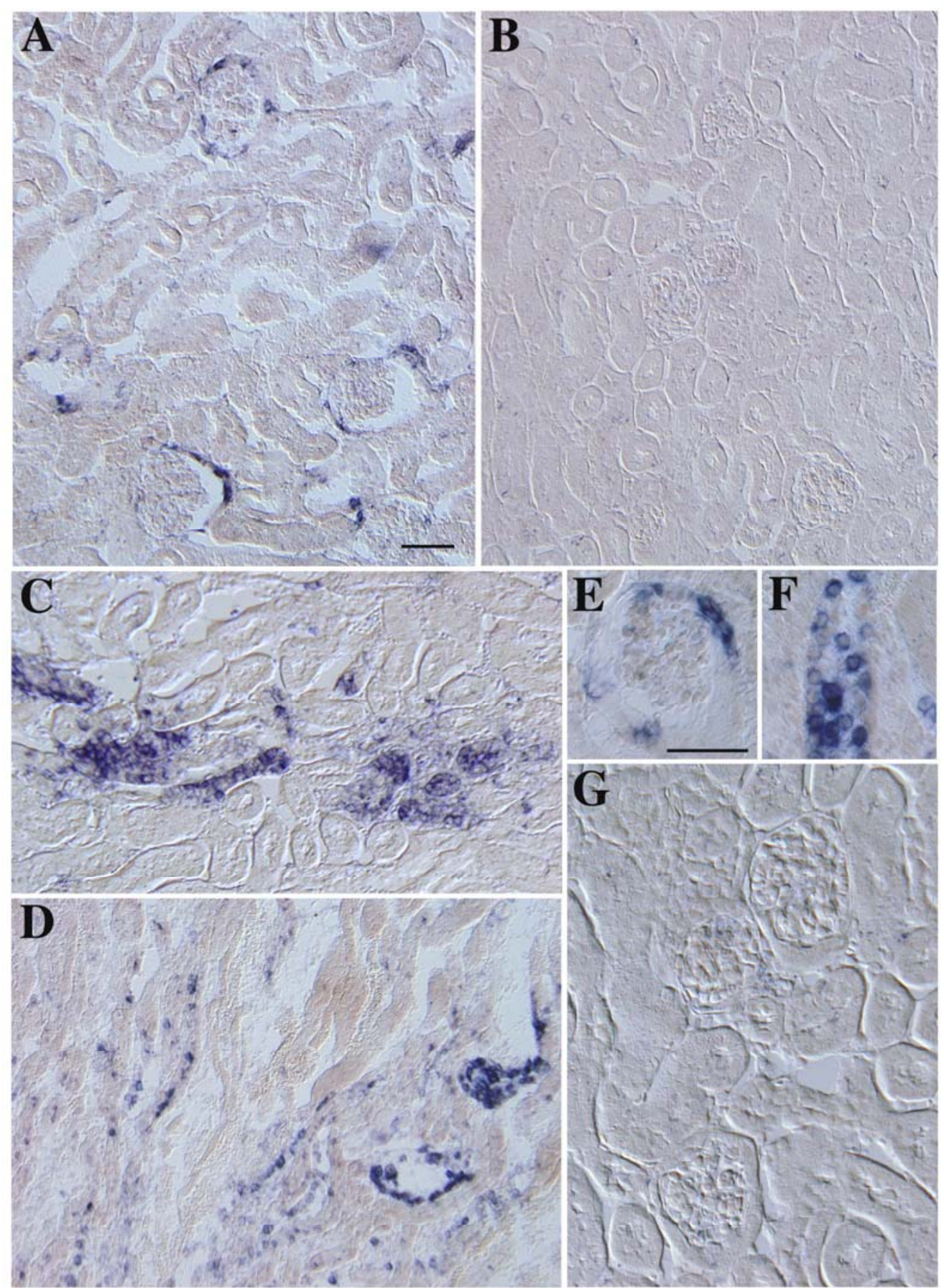


Fig. 6

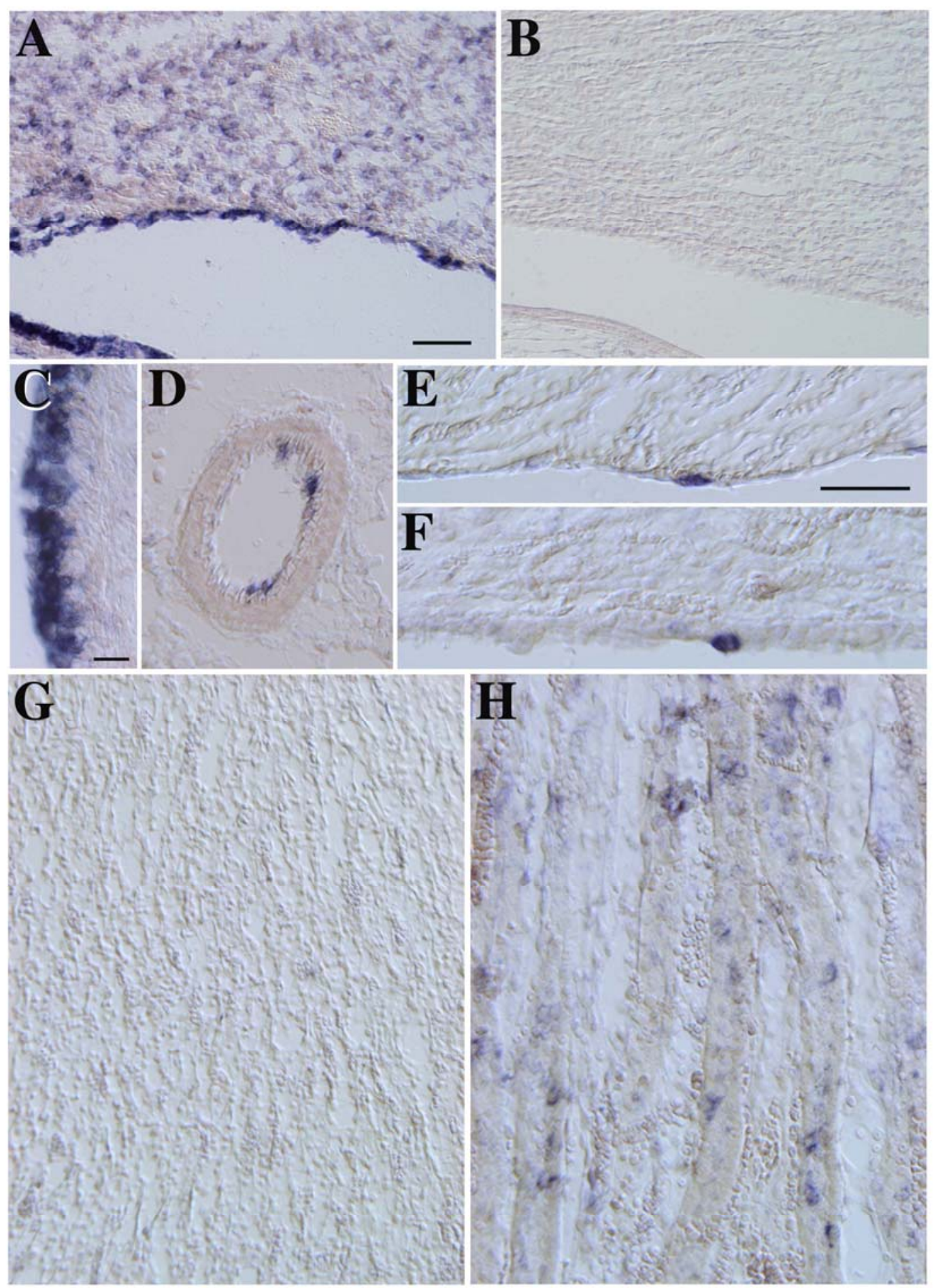



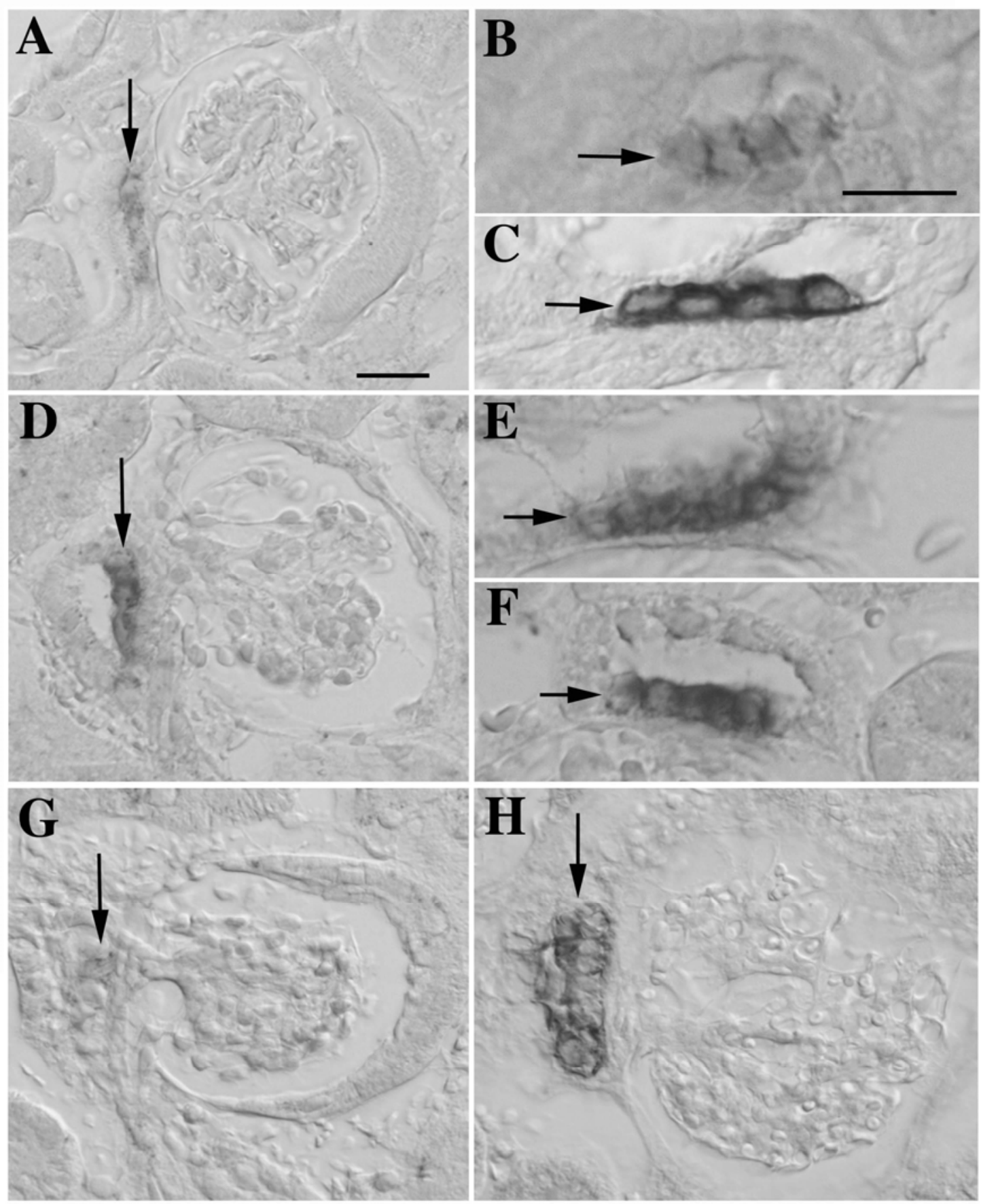
Holmqvist et al 2006
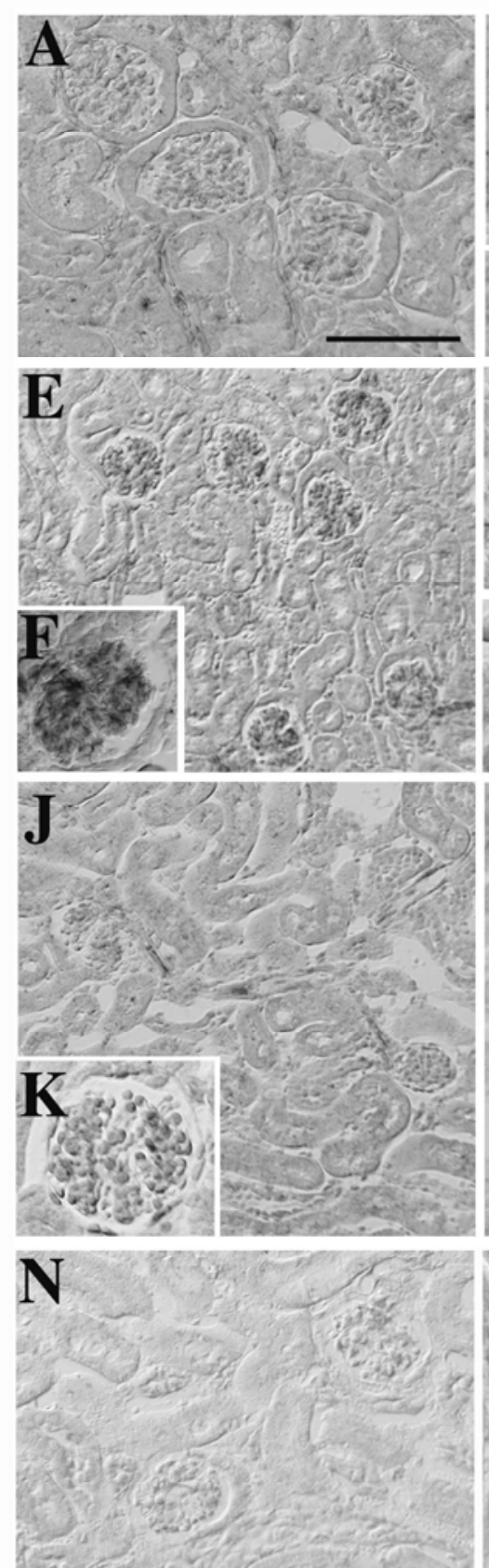
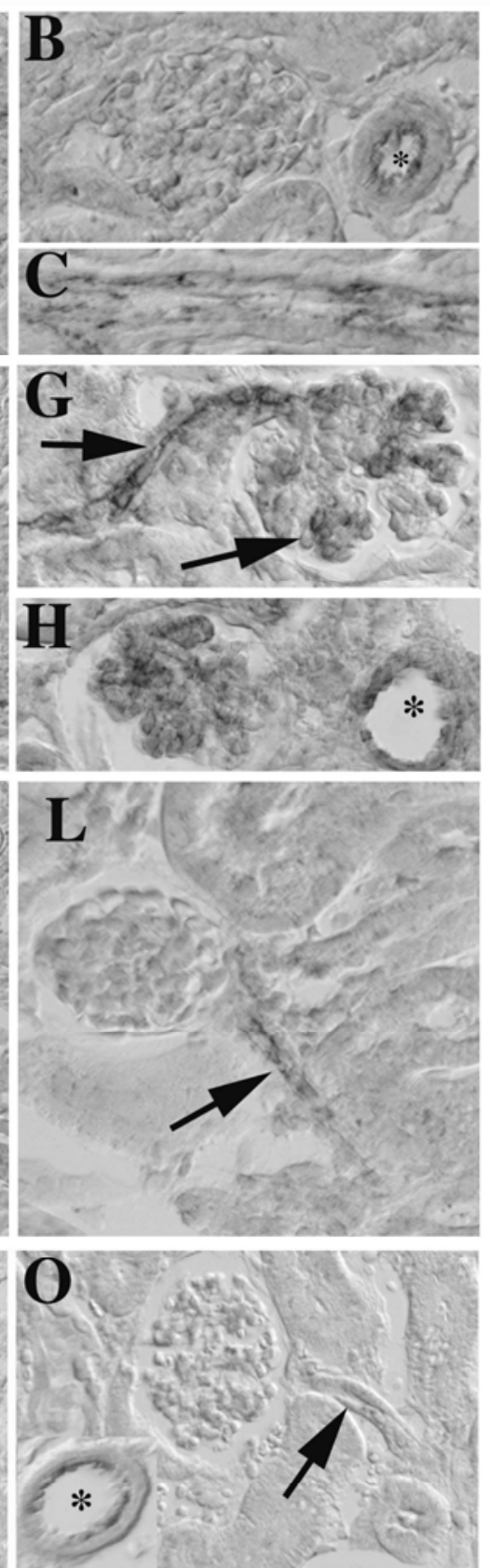

Figure 8
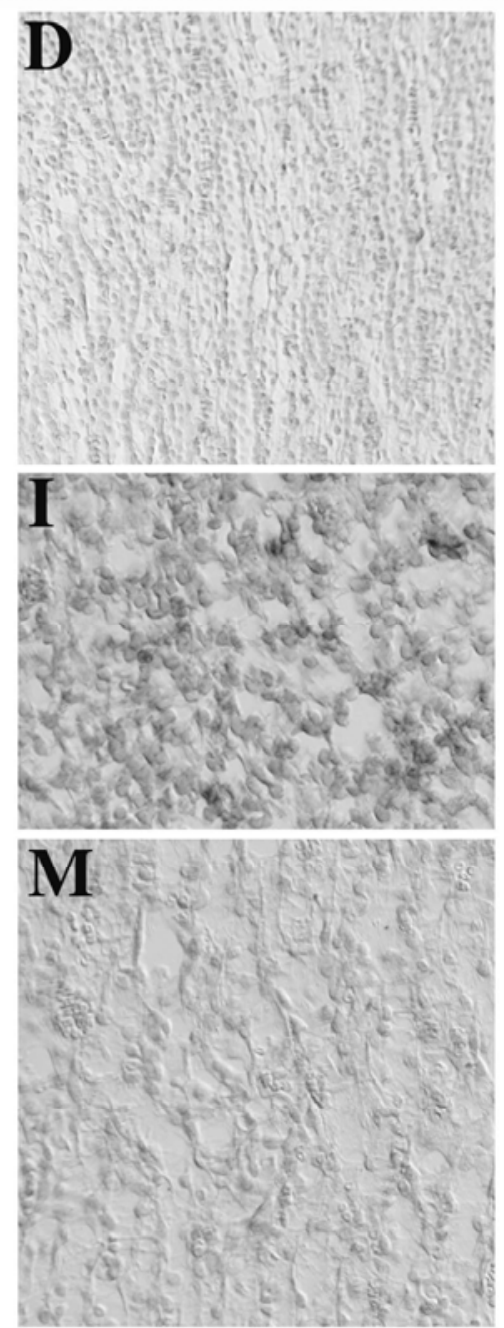